\title{
Abdominal wall metastasis (recurrence) in uterine cervix carcinoma: Report of 2 cases
}

\section{Serviks kanserinin karın duvarı tutulumu: Nadir iki vaka sunumu}

\author{
Ayșegül Öksüzoğlu ${ }^{1}$, Sevim Turanlı ${ }^{2}$, Aylin Kalınbaçoğlu ${ }^{3}$, Nilüfer Çetinkaya ${ }^{1}$, Özlem Yörük ${ }^{1}$, Ali Levent \\ Şirvan ${ }^{4}$, Tayfun Güngör ${ }^{1}$
}

${ }^{1}$ Zekai Tahir Burak Kadın Sağlığı Eğitim Ve Araştırma Hastanesi, Jinekolojik Onkoloji Kliniği, Ankara, Türkiye ${ }^{2}$ Dr. A. Y. Ankara Onkoloji Eğitim Ve Araştırma Hastanesi, Genel Cerrahi Kliniği, Ankara, Türkiye ${ }^{3}$ Zekai Tahir Burak Kadın Sağlığı Eğitim Ve Araştırma Hastanesi, Genel Cerrahi Kliniği, Ankara, Türkiye ${ }^{4}$ Zekai Tahir Burak Kadın Sağlığı Eğitim Ve Araştırma Hastanesi, Patoloji Kliniği, Ankara, Türkiye

\section{ÖZET}

Serviks kanseri dünyada kadınlarda en sık görülen dördüncü kanser türüdür. Hastaların \%30'unda ilk 2 yıl içinde rekürrens saptanır. En sık görülen rekürrens yerleri parametrium, pelvik lenf nodları ve vajinadır. Uzak organ metastazları en sık karaciğer, akciğer ve kemik dokuda görülür. Yumuşak doku, iskelet kası ve abdominal duvarda metastatik tutulum son derece nadirdir. Abdominal duvarda dren yeri ve insizyon yerinde, laparaskopi sonrası port giriş yerlerinde tümör tutulumları bildirilmiştir. Biz nadir görülmesi nedeniyle iki vakada skuamöz hücreli serviks kanserinin abdominal duvarda metastatik tutulumunu rapor ettik.

Anahtar Kelimeler: Serviks kanseri, rekürrens, abdominal duvar, metastaz

\begin{abstract}
Cervix carcinoma is the fourth most common cancer in women in the world. In $30 \%$ of patients recurrence occurs in the first 2 years. It is mostly recurs in parametrium, pelvic lymph nodes and vagina respectively. It metastasizes most frequently to liver, lung and bones. Metastasis to soft tissue, skeletal muscle or abdominal wall is too rare. In the literature, it has been reported tumor involvement of the entrance of drainage catheter or abdominal wall incision or entrance of ports after laparoscopy. We have reported here 2 cases of abdominal wall metastasis of squamous cell cervix carcinoma since it was seen rarely.
\end{abstract}

Keywords: Cervical carcinoma, recurrence, abdominal wall, metastasis

\section{Giriş:}

Düzenli tarama programlarıyla görülme oranı düşürülmeye çalış1lsa da, serviks kanseri tüm dünya kadınlarında meme, kolorektal ve akciğer kanserinden sonra dördüncü sıklıkla görülmektedir (1). Adjuvan radyoterapi uygulamasıyla birlikte lokal kontrolün daha iyi sağlanmasına ve bu nedenle hastalıksız sağ kalım süresinde artış görülmesine rağmen olguların \%20-30'unda siklıkla primer tedavi sonras1 18-24. ayda rekürrens saptanmaktadır. Rekürrens oranları hastalık evresine, primer tedavi modalitesine ve uygulanan adjuvant tedavi yaklaşımına bağlı olarak değişmekle birlikte evre IB olgularda \%10, IIA olgularda $\% 17$, IIB olgularda $\% 23$, III olgularda $\% 42$ ve evre IV olgularda \%74 olarak bildirilmiştir (2).
Serviks kanserinin abdominal duvar, yumuşak doku, iskelet kası, deri ve subkutan doku metastazları son derece nadirdir (3). Biz iki vakada nadir görülmesi nedeniyle skuamöz hücreli serviks kanserinin abdominal duvarda metastatik tutulumunu rapor ettik.

\section{Olgu Sunumu 1:}

56 yaşında kadın hasta karın ağrısı ve vajinal kanama şikâyeti ile hastanemize başvurdu. Jinekolojik muayenede servikse lokalize tümöral oluşumdan biyopsi alındı. Patoloji sonucu non keratinize büyük hücreli skuamöz hücreli karsinoma olarak raporland1. Metastatik hastalık tespiti amaciyla abdomen ve pelvik tomografi incelemeleri yapıldı, uzak organ 
metastazı saptanmadi. Anestezi altında yapılan değerlendirmede vajen arka duvara uzanım gösteren $4 \mathrm{~cm}$ 'lik tümöral oluşum izlenmesi nedeniyle evre IIA1 servix kanseri tanısıyla radikal histerektomi ve pelvik paraaortik lenf nodu diseksiyonu yapıld. Hastaya adjuvan amaçlı pelvik radyoterapi uygulandı. Düzenli takip protokolüne uymayan hasta 2 y1l sonra yaygın karın ağrısı şikâyeti ile hastanemize başvurdu. Fizik muayenede karın duvarında sol paramedian alanda $3 \times 4 \mathrm{~cm}$ 'lik sert hareketsiz kitle palpe edildi. Yapılan jinekolojik muayene, smear testi ve akciğer grafisi normal olarak değerlendirildi. Hastada metastatik hastalık düşünülmesi nedeniyle toraks ve abdomen tomografisi çekildi. Tomografide batın ön duvarında rektus kasına kadar uzanan 3.6x 4 cm' lik kitle lezyonu görüntülendi, uzak metastaz veya cuff rekürrensine ait bulgu saptanmadi. Karın duvarında tespit edilen kitleye geniş cerrahi eksizyon yapılmasına karar verildi. Sol paramedian kesi ile batın duvarından rektus kasına kadar uzanan ve kas dokusuna invaze 5 cm' lik solid kitle cerrahi sınır gözetilerek geniş eksize edildi. Patoloji sonucu: squamöz hücreli karsinom metastazı olarak raporland (resim 1). Hastaya 3 kür platin bazlı kemoterapi verildi. 5 ay sonra hasta kaybedildi.

\section{Olgu Sunumu 2:}

1,5 yıl önce Evre IIA serviks kanseri tanısıyla radikal histerektomi ve pelvik paraaortik lenf nodu diseksiyonunu takiben adjuvan pelvik radyoterapi alan 55 yaşında kadın hasta karın sağ yan duvarda ele gelen ağr1lı kitle nedeniyle hastanemize başvurdu. Muayenede sağ üst kadran lateralde sınırı net olmayan karın duvarı ve alt kaburgalarla iştiraki olduğu düşünülen fikse 7-8 cm' lik kitle saptandi. Jinekolojik muayenesi, smear testi, akciğer grafisi ve biokimyasal analizler normaldi. Toraks ve abdomeni içeren tomografik incelemede pelvik ve paraaortik lenfadenopati ve pelvik lokal nüks bulgusuna rastlanmazken, karaciğer sağ lop posterior segment inferoposterior sinırdan batın duvarına egzofitik uzanan $57 \times 46 \mathrm{~mm}$ boyutlarında lobule, kalın cidarlı solid kitle lezyon izlendi. tru-cut biopsi yapıldı, sonuç epitelyal tümör metastazı olarak raporlandı. Hasta genel cerrahi kliniğine konsülte edildi ve kitlenin total çıkarılmasına karar verildi. Eksplorasyonda sağ hepatik fleksuraya yapışık, karaciğer inferolateral sınırından retroperitona uzanan, gerota fasiasına yapışı, batın duvarına infitre, fikse $8 \mathrm{~cm}$ 'lik kapsüllü tümoral kitle izlendi. Kitle karaciğer ve alt kotlara invazeydi. Batın içinde başka patoloji saptanmadı. Karaciğer segment 7 ve 11-12. kotları da içine alacak şekilde kitle total eksize edildi. Patoloji sonucu; az diferansiye yassı epitel hücreli karsinom metastazı olarak raporland. Hastaya adjuvan tedavi olarak sisplatin-5fluorourasil içeren kemoterapi planland1, ancak hasta 1 kür tedavi sonras1 kemoterapiyi kabul etmedi. Operasyondan 10 ay sonra hasta operasyon lojunda ağrılı ele gelen kitle nedeniyle tekrar başvurdu. Batın duvarında önceki ameliyat alanında 10x15 cm nüks tümör ve gelişen nekroza bağlı olduğu düşünülen apse izlendi. Apse drenaj1 ve antibiyotik tedavisi verilen hasta yaygin hastalık nedeniyle 3 ay sonra kaybedildi.

\section{Tartışma:}

Serviks kanserinin yayılımı genellikle direkt lokal yay1lım ve lenfatikler yoluyla parametrium, pelvik lenf nodları ve vajinaya olurken, uzak organ metastazları en sik karaciğer, akciğer ve kemik dokuda görülür. Literatürde beyin, orbita, meme, kalp, perikard, oral kavite yumuşak dokusu, tiroid, böbrek, over, labia, bağırsak, ve dalak gibi nadir organ tutulumları da rapor edilmiştir (4). Abdominal duvarda serviks kanserinin yayılımı oldukça nadirdir. Literatürde ileri evre, metastatik hastalıkta ve immunsüprese hastalarda rapor edilmiştir. Abdominal duvarda, dren yeri, epizyotomi ve insizyon skarı üzerinde, umblikusda, laparaskopi ve robotik cerrahi sonrası sonrası port giriş yerlerinde tümör nüksleri bildirilmiştir (5). Cilt metastazlarının en s1k görüldüğ̈̈ yerlerden biri de abdominal duvardır. Dermal ve supdermal alanda nodül, ülser veya plak şeklinde görülürler, lokalizasyona göre deformite oluşturabilirler.

$$
\text { Karın duvarı metastazlarında }
$$

etiyolojide birçok faktör suçlanmıştır. Cerrahi sırasinda insizyon yerine direkt implantasyon, mikrosirkülasyondaki fibrin platelet depozitlerinin tümör hücrelerini hapsetmesi, yara hipoksisi, insizyon bölgesinde anjiogenezise yol açan asidotik ortam, ileri evre hastalık, peritonitis karsinomatoza, lenf nodlarına yayılım ve adenokarsinoma hücre tipi sayılabilir(6). Biz bir vakamızda paramedian alandan rektus kasına kadar uzanan kitle tespit 
ederken, diğer vakada metastaz yeri insizyon hattından uzaktaydı ve hastalık yinelemesi 1112. kotları ve karaciğeri kısmen invaze etse de lokalizeydi.

İmachi ve ark. serilerinde abdominal duvar metastazlarında tümör tipinin önemli olduğunu ve adenokarsinomların skuamöz hücreli karsinomlara göre 6 kat daha fazla görüldügünü bildirdiler (7). Ancak bizim her iki vakamızda da hücre tipi skuamöz hücreli karsinomdu.

Karın duvarı metastazı gelişen hastalarda karın duvarında ağrı şikâyeti olabileceği gibi hastalar tamamen asemptomatik olup, kitle muayene esnasinda saptanır. Dikkatli ve özenli yapılacak bir muayene ve görüntüleme teknikleri ile abdominal duvar metastazlarının tanıs1 konabilir. Vakalarımızın ikisi de ağrı nedeniyle hastaneye başvurmuş ve muayene sırasında kitle tespit edilmişti. Uygun vakalarda tanı için biyopsi alınması gerekir. Kesin tanı histopatolojik inceleme ile konulmalıdır. Prognoz kötüdür. Karın duvarı metastazlarında ve skar rekürrenslerinde ortalama yaşam süresi 8,5 aydir(7).

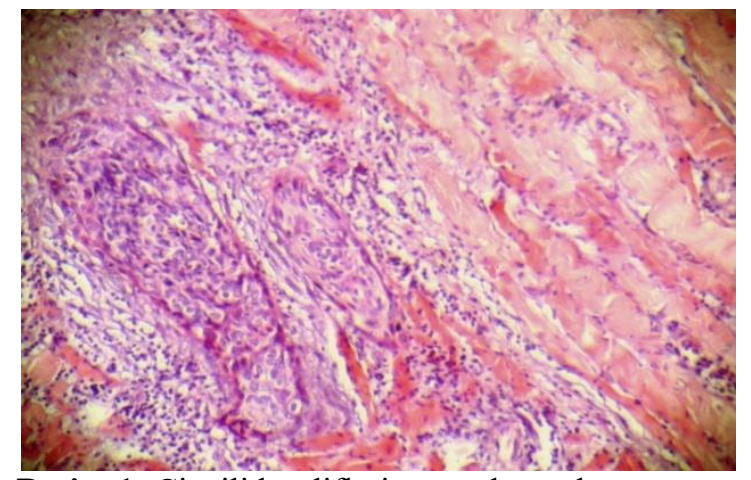

Resim 1: Çizgili kas lifleri arasında scc hücre adalar1 (20x)

\section{Referanslar}

1. Pimple S, Mishra G, Shastri S. Global strategies for cervical cancer prevention. Curr Opin Obstet Gynecol. 2016 Feb;28(1):4-10

2. Sardain H, Lavoue V, Redpath M, Bertheuil N, Foucher F, Levêque J. Curative pelvic exenteration for recurrent cervical carcinoma in the era of concurrent chemotherapy and radiation therapy. A systematic review. Eur J Surg Oncol. 2015 Aug;41(8):975-85.

3. Fulcher AS, O'Sullivan SG, Segreti EM, Kavanagh BD. Recurrent cervical carcinoma: typical and atypical manifestations. Radiographics. 1999 Oct;19:103-16.
Tedavi hastalığın yaygınlığına göre bireyselleştirilmelidir. Yaygın ileri evre hastalık ve uzak organ tutulumlarında radikal tedavi yapılamazken, lokalize karın duvarı metastazlarında geniş cerrahi eksizyon, kemoterapi, ve radyoterapi tercih edilebilir (8). Geniş eksizyon ve kemoterapi kombinasyonu en çok tercih edilen seçenektir (8). Platin bazlı kemoterapiler tercih edilir. Cerrahi sonras1 radyoterapi uygun vakalarda uygulanabilir. Lokalize, soliter ve cerrahi rezektabl kitlelerde metastazektomi uygun yaklaşımdır. Geniş kitle eksizyonlarında abdominal duvar rekonstrüksiyonu gerekebilir. Deri ve supkutan dokuyu kapsayacak alacak şekilde geniş eksizyonlarda flep ve meshler kullanılmaktadır (9).

\section{Sonuç:}

Serviks kanserinde radikal cerrahi sonrası abdominal duvar metastazı nadir görülen bir durumdur. Serviks kanseri tanisı ile izlenen hastalarda karın duvarında kitle tespit edildiğinde metastatik tutulum akla gelmelidir.

\section{Çıkar Çatışması: Yok}


the literature. Case Rep Obstet Gynecol. 2012;2012:593732.

7. Imachi M, Tsukamoto N, Kinoshita S, Nakano H. Skin metastasis from carcinoma of the uterine cervix. Gynecol Oncol. 1993;48:349-354.

8. Sharma DN, Chawla S, Chander S, Gairola M, Thulkar S, Singh MK. (2000). Cervical carcinoma recurring in an abdominal wall incision. Clin Oncol. 2000;12(6):354-6.
9. Neven P, Shepherd JH, Tham KF, Fisher C, Breach N. Gynecol Oncol. Reconstruction of the abdominal wall with a latissimus dorsi musculocutaneous flap: a case of a massive abdominal wall metastasis from a cervical cancer requiring palliative resection, Gynecologic Oncology. 1993; 49: 403-06 